(C) The Author(s), 2021. Published by Cambridge University Press for the Arizona Board of Regents on behalf of the University of Arizona

\title{
DR. UGO ZOPPI (1965-2016): IN MEMORIAM
}

Michael Hotchkis*(D) - David Fink • Quan Hua (1) - Andrew Smith

Australian Nuclear Science and Technology Organization (ANSTO), Kirrawee DC, New South Wales 2232, Australia

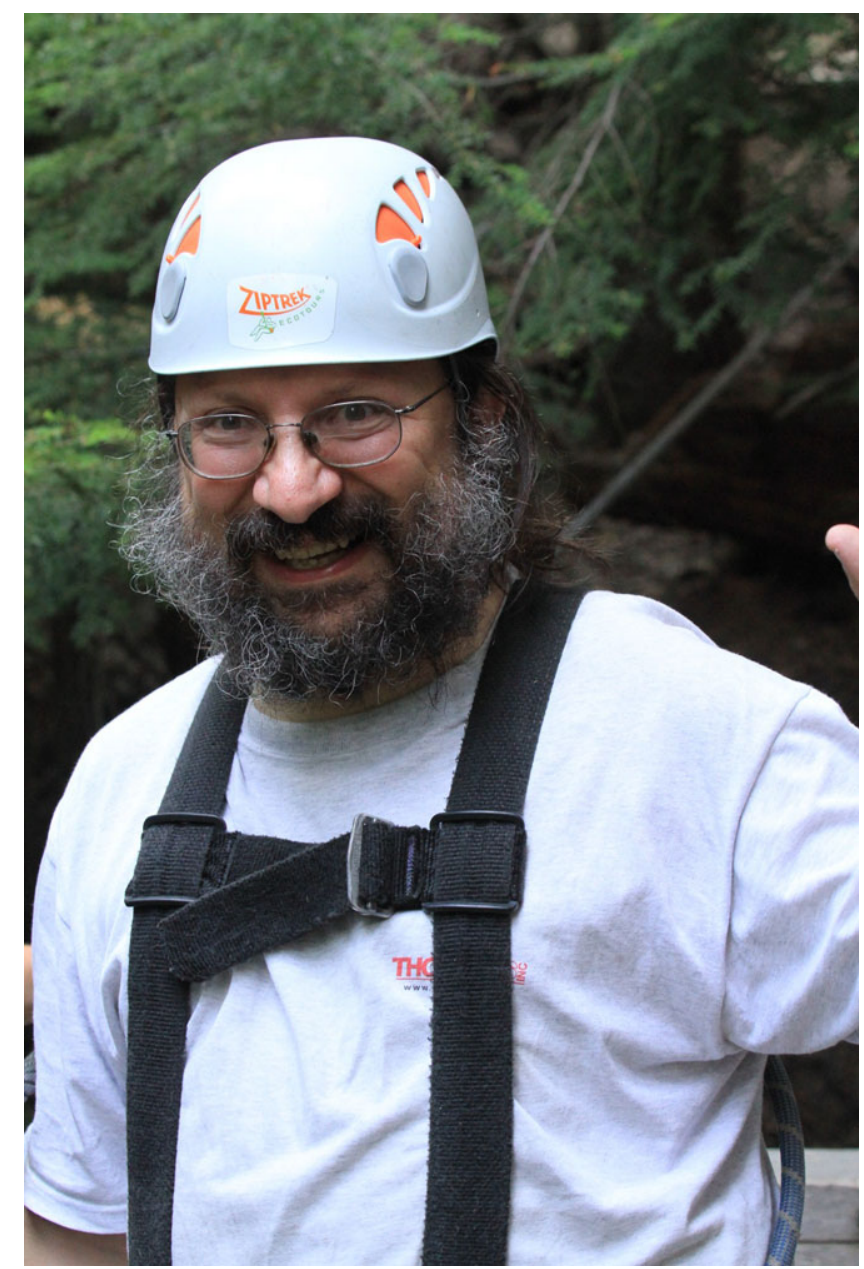

Ugo, ready as always for an adventure (credit: Mary Zoppi).

Dr Ugo Zoppi grew up in Switzerland in the Italian-speaking Canton of Ticino and achieved recognition for excellence in AMS radiocarbon research in the fields of biomedicine and archaeology. Ugo's career started at Eidgenössische Technische Hochschule (ETH) in Zürich, where he studied for his $\mathrm{PhD}$ under the supervision of Professor Martin Suter. At ETH he developed his AMS expertise with the commissioning of a purpose-built gas-filled

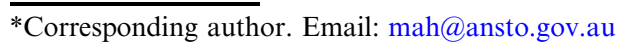


magnet detection system and applied it to the separation of ${ }^{32} \mathrm{Si}$ and ${ }^{36} \mathrm{Cl}$ from their respective sulphur isobars.

Following his $\mathrm{PhD}$, Ugo made his first inter-continental move to take up a post-doctoral position at the University of Tokyo. With the new location came a new scientific direction: studying extra-terrestrial materials. He used AMS to investigate radioisotope concentrations in cosmic spherules extracted from deep-sea ocean sediments. Whilst in Tokyo he met Mary Kondrat and they were married in 1997.

Later that year Ugo made his second inter-continental move, to Sydney, Australia, to work with us at ANSTO. Ugo pursued a wide variety of work at ANSTO, including development of software for statistical analysis of our AMS data, still in use today. He focussed on using AMS for radiocarbon analysis, pursuing studies in archaeology, for which he had a great interest, as well as in climate science. He pioneered studies at ANSTO using bomb-pulse radiocarbon dating for forensic analysis of illicit drugs and for authentication of wine vintages, somewhat paradoxical for a man of moderation!

Ugo and Mary's daughter Grace was born in 2000, when they were living in Engadine-the suburb of Sydney-not the better-known Swiss valley! 2000 was a big year for Sydney as host of the Olympic Games and, as Ugo loved a spectacle, he did not miss the opportunity to attend the opening ceremony and other events.

When I returned from the AMS-10 Conference in Berkeley, California, in 2005, Ugo surprised me by saying he had obtained a Green Card and that he would be leaving us to start a new life with his family in Washington state, where his wife Mary grew up and had family. "There's a new start-up company in Seattle, getting an AMS system for biomedical applications-I heard about it at the conference," I told him. "Are they advertising a job?" Ugo asked. "Don't wait, just get in touch with them," I suggested. So, Ugo's career took another turn with a third intercontinental move. In 2006 Ugo joined Accium Biosciences as its first Director of the AMS facility, and he managed their operations, this time in an entrepreneurial environment, still able to find opportunities to pursue his interest in archaeology from time to time. At Accium he pioneered protocols that allowed archeological and "hot" spiked biomedical samples to be prepared and measured at the one AMS facility. He enjoyed family trips near and far, not least into the Cascade Mountains on his doorstep, until his untimely death in March 2016.

\section{SELECTED PUBLICATIONS}

Asenstorfer RE, Jones GP, Laurence G, Zoppi U. 2011. Authentication of red wine vintage using bomb-pulse ${ }^{14} \mathrm{C}$. ACS Symposium Series 1081:89-99.

David B, Crouch J, Zoppi U. 2005. Historicizing the spiritual: $\mathrm{Bu}$ shell arrangements on the Island of Badu, Torres Strait. Cambridge Archaeological Journal 15(1):71-91.

Hua Q, Barbetti M, Fink D, Kaiser KF, Friedrich M, Kromer B, Levchenko VA, Zoppi U, Smith AM, Bertuch F. 2009. Atmospheric ${ }^{14} \mathrm{C}$ variations derived from tree rings during the early
Younger Dryas. Quaternary Science Reviews 28(25-26):2982-2990.

Zoppi U, Arjomand A. 2010. Simultaneous AMS determination of ${ }^{14} \mathrm{C}$ content and total carbon mass in biological samples. Nuclear Instruments and Methods in Physics Research B 268(78):1307-1308.

Zoppi U, Kubik PW, Suter M, Synal H-A, von Gunten HR, Zimmermann D. 1994. High intensity isobar separation at the Zürich AMS facility. Nuclear Instruments and Methods in Physics Research B 92(1-4):142-145. 
Zoppi U, Matsuzaki H, Kobayashi K, Imamura M, Nagai H, Hatori S, Nakano C, Sunohara Y. 1997. New interpretation of the ${ }^{10} \mathrm{Be}$ and ${ }^{26} \mathrm{Al}$ content in cosmic spherules. Nuclear Instruments and Methods in Physics Research B 123(14):319-323.

Zoppi U, Hua Q, Jacobsen G, Sarkissian G, Lawson EM, Tuniz C, Laurencich Minelli L. 2000. AMS and controversies in history: the Spanish conquest of Peru. Nuclear Instruments and Methods in Physics Research B 172(14):756-760.

Zoppi U, Skopec Z, Skopec J, Jones G, Fink D, Hua Q, Jacobsen G, Tuniz C, Williams A. 2004. Forensic applications of 14C bomb-pulse dating. Nuclear Instruments and Methods in Physics Research B 223-224:770-775. 